\title{
THE EUROPEAN UNION, INDONESIA, AND THE RENEWABLE ENERGY DIRECTIVE
}

\author{
${ }^{1}$ Rosario J Taa, ${ }^{2}$ Jhon Jefri Rumbino, ${ }^{3}$ Yoel Parakletos Pandiangan, ${ }^{4}$ Renata Iglesyanna, \\ ${ }^{5}$ Karinda Febrinia, ${ }^{6}$ Christy Melvadera Sitompul \\ ${ }^{123456}$ International Relations, Universitas Kristen Indonesia, Jakarta \\ ${ }^{1}$ rafaeltaamomo28@gmail.com, ${ }^{2}$ jhonjefriwresman2017@gmail.com, ${ }^{3}$ parakletos.joel2@gmail.com, \\ ${ }^{4}$ ceciliarenata18@gmail.com, ${ }^{5}$ karin.vksl@gmail.com, ${ }^{6}$ christymelva99@gmail.com
}

\begin{abstract}
This research tries to explain how to overcome the problems that occur in the relation between EU (European Union) and Indonesia regarding renewable energy directive. The main concept that we research is based on environmental diplomacy by doing literature review. The concept of environmental diplomacy is used to explain the environmental conflict between the EU and Indonesia that occured and how it effect the environment, especially the renewable energy directive.
\end{abstract}

Keywords: EU Clean Energy, Diplomacy, Indonesia, Environment.

DOI: 10.33541/sp.v21i1.1587

Sociae Polites : Majalah IImiah Sosial Politik

Faculty of Social and Political Science, Universitas Kristen Indonesia

ISSN 1410-3745 print/ ISSN 2620-4975 online

Volume 21, Number 1 (January - June 2020)

Pages 21-40 


\section{Introduction}

Energy is very important for a country. Energy has an important role, namely as a source of state revenue, fuel, and industrial raw materials, driving economic activity and several other important roles. Therefore, a country must manage energy well. Since 2005 Indonesia has been offering as the world's largest producer of palm oil. The volume of Indonesia's palm oil exports in 2015 reached 26.4 million tons or worth 18.6 billion US dollars. Indonesia's palm oil industry is considered to be part of a negative campaign because it causes environmental destruction or deforestation.

A large number of human exploitation of the environment, such as petroleum, oceans, destruction of flora and fauna habitats, and various other environmental problems, there will be an increasingly diverse increase on a global scale. So far, Indonesia's palm oil exports have been issued by crude palm oil (CPO). Industrial crude palm oil (CPO) is a significant contributor to finance in Indonesia. CPO production has become a type of income that can be relied upon by many poor people in Indonesia. One of the biggest $\mathrm{CPO}$ consumers and a potential market for Indonesia is the European Union. This area uses CPO as the main raw material in the field that can produce biofuels. which is a renewable energy that is being developed by the European Union as a form of concern in addressing environmental problems. This technology was created to overcome the scarcity of energy by utilizing renewable resources obtained from biological materials.

The European Union issued the latest policy on biofuels that are released from the marine oil, namely the Renewable Energy Directive (RED). RED is a policy approved by the EU in replacing greenhouse gas emissions of at least $20 \%$ and increasing the use of renewable energy by $20 \%$ in energy consumption by 2020 . RED sets national goals, which link with the law according to indicative targets for the renewable energy section.

RED also addresses the issue of renewable energy in the transportation sector using biofuels, where RED sets a binding target of $10 \%$ for 2020. RED also stipulates provisions to facilitate the development of renewable energy. The latest energy usage correlations show the significant influence of energy use has contributed to falling prices in large countries that use more renewable energy and price increases in many countries that use less renewable energy. Costs and benefits derived from a comparison between the price of electricity incurred with the price and the comparison born with the loss of fossil fuels. Net profit of 47 billion euros in the entire oil price cycle caused by the use of renewable energy, which averages 8 billion euros per year. This net benefit is higher than the total community support for renewable energy. The net profit will be more significant if the EU asks for higher oil prices through more public support for low oil prices because this will create productive capacity. Still, the interests of the country are increasingly different. EU anti-cyclic policy recommended.

The commission's original proposal did not include the transportation sub-target, which was agreed by the co-legislators in the final agreement: the Member States must request fuel suppliers to supply at least $14 \%$ of the energy needed in road and rail transportation by 2030 as renewable energy. The Directive 2009/28/EC sets national renewable energy targets for 2020 for each country, taking into account the starting point and overall potential for renewable energy. The 10\% target in Malta to the highest is $49 \%$ in Sweden. EU countries agree on their target to meet this 2020 target and their general renewable energy policy direction in the national renewable energy action plan. Progress towards the target is expected every two years EU countries publish plans to increase national renewable energy. 


\section{Literature Review}

Environmental diplomacy is defined as an affiliation of tools and approaches used to help disputants create cooperation opportunities, build trust and conflict resolution related to environmental issues, and shared natural resources. What is characteristic of this diplomacy is the importance and critical thinking about the attitude of prevention, management, and conflict resolution regarding natural resources. Oil, minerals, wood, land, and water are natural resources that can sustain the lives and livelihoods of people throughout the world. Ecological globalization, which is driven by facts about the correlation between production and consumption carried out between countries, reminds us that every policy taken by the state will affect the survival of other countries.

According to Borg (1994), Environmental diplomacy can be interpreted as the skill in handling environmental issues, whose implications are international in scope. The main objectives achieved in environmental diplomacy include trying to try to apply international environmental law and continue with what has been agreed upon. This international environmental law has given rights and obligations that maintain a balance system between states, non-state units, and other international communities. Therefore environmental diplomacy will play an influential position in the international political system.

Environmental diplomacy, as one of the new branches that have arisen in the field of diplomatic relations, is inseparable from the influence of the emergence of environmental issues that have been raised as a matter of global politics. Since the 1972 Stockholm Declaration was declared, environmental issues that were once scientific are now being built to problems of politics and international relations. The principles in the declaration provide many illustrations that the concepts of development and the environment are not just separated. To apply these international principles to the national idea certainly requires a struggle through diplomatic channels. One of these efforts is through the model of diplomatic conferences (diplomatic conferences), which are pioneered by many international bodies.

The EU-Indonesia oil palm dispute is a case for formulating EU environmental diplomacy. The EU renewable energy direction (RED) is a sign of goal-oriented natural tact that centers around turning around monetary globalization and restricting financial development. The low carbon economy is likewise the objective of a sustainable power source course. The low carbon economy in EU natural discretion implies that there must be respectable objectives in the EU outside and interior arrangements. The standards for the achievement of EU ecological discretion depend not just on expanding the pace of financial development of the EU and its accomplices yet besides on the capacity of the EU to coordinate social equity and natural security.

\section{Results and Discussion}

The EU-Indonesia oil palm dispute is a case for detailing EU natural discretion. EU ecological discretion is an endeavor to move EU rules, guidelines, and outside natural targets to third nations and worldwide associations. Types of EU ecological discretion incorporate control of utility estimations, limit building, and discourse, and exchange. The EU sustainable power source course (RED) The EU is an indication of aspiring ecological discretion that centers around switching financial globalization and restricting 
monetary development. The low carbon economy is likewise the objective of sustainable power source heading. Petroleum derivatives are the fundamental driver of environmental change in light of its notoriety for being the most significant maker of carbon dioxide.

In any case, sustainable power sources are still will be a discussion. The utilization of wind and sun oriented vitality isn't sufficient to answer European vitality requests. In 2015, sustainable power source just represented $13 \%$ of the comprehensive EU vitality utilization, surpassing the measure of oil and strong energizes by $50.6 \%$ (European Union, 2017). Atomic vitality is an extremely questionable option on account of the danger of a nuclear release like the one in Fukushima, Japan, in 2011. Biofuels from palm oil come seen as appealing possibilities as a result of value gains (Reuters, 2018). In 2019, Ambassador Guerend said the number of biofuel imports from Indonesia and Malaysia to the EU expanded fundamentally because of the utilization of RED.

EU reacts about biofuels, and there is analysis with regards to whether biofuels meet all requirements for being classified as a sustainable power source. Pundits of the execution of RED are that "specifically an expansion in crop interest for biofuels can contribute in a roundabout way to expanded weight on woodlands and other carbon-rich environments, and henceforth increment emanations from land-use change. Such discharges generally expected to happen in third nations, where the new creation is probably going to be acknowledged at the most reduced cost (European Union, 2016)".

The low carbon economy in EU natural tact implies that there must be important objectives in the EU outside and inside approaches. As indicated by Ambassador Fardo (2019), the EU gave restrictive access to developing nations to the EU advertise as a feature of the EU crucial conquering social bad form in International Relations. For this situation, an exchange is a type of a political apparatus for political purposes. The models for the achievement of EU natural tact depend not just on expanding the pace of financial development of the EU and its accomplices yet additionally on the capacity of the EU to incorporate social equity and ecological assurance.

\subsection{Renewable Energy Directive 2009}

The policy of sustainable development arises from the background of the conditions of dependence on EU fossil fuel energy sources. Initially, the European Council in Göteborg in 2001 formulated the first EU Sustainable Development Strategy (SDS), which is a blueprint for implementing an EU development policy that is more dependent on renewable energy sources. Because it is still in a strategic form, this blueprint does not have the force of law to bind its object, namely the European Union countries. After going through a series of amendments, including the changes in the 20052009 period. In 2009, Directive 2009/28/EC was approved by the European Parliament and the Council (European Parliament \& Council of the European Union 2009).

Following the provisions of the European Union law, Directives 2009/28/EC compilation based on the Treaty of Lisbon or what is officially referred to as the Treaty of the Establishment of the European Community (European Community 1997). The agreement signed on December 13, 2007, and ratified on December 1, 2009, is an amendment to the Treaty of Maastricht and Treaty of Rome, which forms the basis of the EU's constitution and primary legal sources. Because it refers directly to the Treaty of Lisbon, Directive 2009/28/EC is a legitimate product that has more binding forces in member countries and has permanent legal authority compared to SDS (European Community 2015). In general, these Directives are divided into two parts. Namely, the 
first part consists of an introduction that contains a conceptual explanation that forms the basis for the formation of Directives, and the second is the torso of the Directives themselves.

The introductory part explains the concept of Sustainable Development Policy, which is reviewed in correlation with policies in the environmental sector in the Treaty of Lisbon (European Community 2015). Some important points in the introduction are as follows:

a. In points 1-3, it can be found that the design of the EU sustainable development policy also considers the substance of the Kyoto Protocol to reduce the reduction of gas emissions since 2012. Member countries must obey provisions in the European Union that make countries subject to the EU Establishment Agreement make these Directives on Sustainable Development. That is, other countries whose activities intersect with EU member states regarding matters regulated in the EU Establishment Agreement are also affected by this law.

b. The EU Commission has also established a policy evaluation system for member countries on how this policy works in their countries. Directives 2009/28/EC gives freedom to the member states to design the type of sustainable development that is most suitable. Still, the country must also ensure that this program successfully exceeds the minimum standards proposed by the Committee as of 2010. Although this has been permitted, following article 25 , member countries must pay attention to the operationalization, funding, absorption, and efficiency of their renewable energy programs.

c. In the opening part of point 12 also regulates the types of use of agricultural products such as organic residues of animals to produce biogas is considered as one way to mitigate the impact of greenhouse gas emissions. Biogas installations can be designed to follow the regional characteristics of member countries. They must support regional investment structures, including in rural areas, and encourage local farmers the opportunity to increase their incomes. In addition to biogas originating from organic residues of plants or animals, the use of other renewable energy sources, including electricity, is allowed as long as it does not interfere with the stability of electricity prices in the market (point 30). In addition to electricity, several energy sources like wind power, the use of heat pumps from geothermal, aero-thermal, or other heat sources are also permitted.

In the second part, the body generally consists of 29 articles, which are grouped in several categories, which are expected to be a guide for the implementation of sustainable development programs. The rules are contained in these Directives direct the European Union countries towards the use of biofuels as renewable energy replacing fossil fuels. Of course, because one of the goals for biofuels is related to environmental preservation, fuels used by EU member states must also meet the environmental safety standards adopted by the European Union. For this reason, several standard criteria must be met by imported products - in this case, Indonesian CPO products - to be accepted according to the laws and regulations in Europe.

The adoption of the Renewable Energy Directive by the European Union is a step to reduce carbon emissions globally as a form of EU commitment to the Kyoto Protocol. Also, setting a goal for the use of biofuels for EU member states is aimed at reducing dependence on consumption and imports of fossil fuels with the requirement that they must meet sustainability criteria as stipulated in Directive 2009/28/EC. From one 
perspective, this is intended to maintain environmental sustainability and reduce global emissions. Then again, this is considered a new form of obstacle created by the European Union to ensure biofuel products from other countries because so far, the European Union is the main producer of biodiesel. This trade competition resulted in EU implementation of RED being seen as a form of green protectionism through the application of sustainability criteria.

The local vitality needs of EU member countries, especially the demand for oil and gas, must be met through imports. At present most of the EU's energy needs come from imports, and it is estimated that in 2030 its energy imports will increase to $65 \%$ of total EU energy consumption (Paul Belkin, 2007). The European Union is the secondbiggest oil shopper on the planet after the United States. EU oil consumption reaches $20 \%$ of total world oil consumption. Of the aggregate use, $80 \%$ of total consumption is met through imports from Russia, the Middle East, Africa, and Norway (Susanne Nies, 2008: 24). European Union not only depends on oil imports but also highly dependent on gas supplies from Russia, Norway, Algeria, and some countries from the Middle East region. Domestic gas reserves of EU member states (EU-25) are only able to supply a maximum of $41 \%$ of the total domestic gas needs; the rest is met through imports (EU Green Paper, 2006).

Therefore, the European Union pays great attention to energy issues. Energy is a very vital factor in driving economic growth in European Union member countries. For this reason, guaranteeing the security of vitality flexibly for EU member countries is a significant concern of the European Union. To ensure its energy supply, the European Union issued a Solidarity Action Plan to plan medium and long-term actions to secure the domestic energy supply of its member countries (Council of European Union: 2009; Strategic Energy Review: 2008). For the medium and long term plans, the European Union will diversify its supply of non-fossil fuels and develop infrastructure in the energy sector. Renewable energy has a very imperative role in the European Union. Renewable energy is an energy that can be produced by the European Union member countries. Globally, the European Union is one of the leading producers of renewable energy in the field of development technology. This condition is indeed expected by the European Union to reduce its dependence on imported fossil fuels from abroad (European Commission, 2007).

This renewable energy policy was made to reduce dependence on energy imports and secure the domestic energy supply of EU member states. This policy was also made because of global demands to reduce carbon emissions to mitigate climate change. However, in the implementation of the Renewable Energy Directive, on the one hand, it is seen by exporting countries as an opportunity for the creation of new markets for biofuel products.

\subsection{European Palm Resolution}

In April 2017, the European Union Parliament informed a resolution on palm oil and rainforest deforestation. The ultimate goal is to ban imports of oil palm that are not compatible with sustainable development and its derivative products by 2020 into the EU (European Parliament, 2017). The resolution entitled Palm Oil and Deforestation of the Rainforests was submitted sourced on the accusation that the enhancement of the palm oil industry is a significant cause of deforestation and climate change. In a resolution that explicitly mentions Indonesia, it produced 640 votes from members of Parliament who 
agreed, 18 refused, and 28 abstained. This resolution highlights several issues that believe to be in the hands of the Indonesian palm oil industry, and recent years have become the main focus of western countries.

Additionally, the goals encouraged palm oil not to remembered for the class of crude materials in the EU biodiesel program in 2020. Following two months, in June 2017, the Norwegian Parliament likewise gave comparable goals, which encouraged the Government of Norway to boycott the utilization of open obtainment for palm oil items and every one of their subordinates (BPPK, 2017).

This resolution shows discriminatory actions against palm oil-producing countries. It contradicts the EU's situation as a victor of open, rules-based free, and reasonable exchange. Information and data identified with the improvement of palm oil and timberland the executives in creating countries are not accurate and accountable, including data in Indonesia. Also, this resolution neglects the multi-stakeholder approach and includes a negative note on oil palm. Notwithstanding, other things referenced that oil palm is an extreme issue that is related to problems of pollution, youngster work, human rights infringement, abolishing the privileges of indigenous people groups, as a trigger for deforestation, and environmental devastation. The goals likewise suggest the requirement for speculation from palm oil products into sunflower seed oil and canola (Sari, 2017). Endeavors to obstruct the palm oil ventures will bring out through an individual affirmation plot for palm oil entering the EU. Then, gradually the EU will eliminate the utilization of vegetable oil that triggers deforestation, starting in 2020. Resolution made regarding this palm oil does not explicitly mention Indonesia. However, the whole world knows that the biggest palm oil maker on the planet is Indonesia, which is then followed by Malaysia, Thailand, Colombia, and several other producing countries.

Deforestation occurs in protected forests, while Tree Cover Loss (TCL) occurs due to human factors or due to forest fires and other forms of disaster. Based on data from the World Resources Institute (WRI), there has been a decrease in deforestation from 2015 to 2016 (KLHK) (World Resources Institute, 2017). In this case, the TCL that occurs according to Global Forest Watch (GFW) data is indeed 2,422,128 hectares, but from the KLHK data that there has been a reduction in deforestation in Indonesia since 2015 in the area of 1.1 million hectares to 630 thousand hectares. In this case, it is very biased and political in evaluating the development of Indonesian policies related to forest issues.

The issue of deforestation is spreading into a statement from the European Commission stating that "Reviews that Indonesia has as of late become the third-most elevated polluter of $\mathrm{CO} 2$ on the planet and experiences diminishing biodiversity, with a few imperiled untamed life species very nearly terminations." From the results of a 2013 European Commission study, the most important cause of deforestation was the agricultural sector, which reached 58 million hectares, while oil palm only caused 6 million hectares of the total 239 million hectares of deforestation. This data places palm oil as the fourth leading cause of deforestation after soybeans and corn, which contribute around $2.5 \%$ of global deforestation. However, of course, we cannot close our eyes to the rate of deforestation in Indonesia (European Commission, 2013). Most deforestation results in large plantation and mining companies. Over ten years, 2000-2010, the company is responsible for about $88 \%$ of the total area cleared, while land conversion by farmers only accounts for $11 \%$ (Lee, 2014).

This consideration is biased because Malaysia and Indonesia have accused of being the primary source of deforestation due to palm oil. Although the European Parliament expresses its appreciation for the role of Indonesia and Malaysia in 
overcoming the environment related to oil palm plantations, for a long time, these efforts have not resulted in a resolution to help environmental problems. On the contrary, the EU is making allegations of deforestation triggered by oil palm. Also, the statement of the European Parliament does not take into consideration the efforts of the Government of Indonesia in improving the rainforest area. In this matter, according to data from GFW, that what happened in Indonesia, TCL is not the cause of deforestation.

\subsection{Trialogue RED II Europen Union}

The EU decision-making in regards to the Renewable Energy Directive (RED) is fundamental for palm oil makers because there is a chance of a restriction on palm biofuel. RED was first placed into impact on June 25, 2009, and has since become the essential administrative apparatus utilized by Brussels to control the utilization of biofuels. This guideline sets focuses for every part nation concerning sustainable power source use and sets measures that permit biofuels to estimation underneath those sustainable power source targets. As indicated by Oil World, the EU is the biggest biodiesel maker on the planet, with yield arriving at $12.8 \mathrm{MT}$ in 2017. One year from now, it will assess around 3,5MT palm oil to utilize crude material (Palm Oil Today, 2018).

Toward the beginning of January 2018, the European Parliament corrected the RED draft to remember a boycott for the utilization of palm oil biofuels in Europe after 2021. Malaysia and Indonesia intensely contradicted this move. The two nations control practically $90 \%$ of worldwide palm oil trades. As a component of the RED structure affirmed by individuals from the European Parliament, the sustainable power source will contribute at any rate of $35 \%$ of the general EU vitality use by 2030 . Biofuels produced using food, and other food harvests will be decreased to zero by 2030 under the RED arrangement Parliament. The EU is an innovator in endeavors to alleviate environmental change. The understanding came to the EU RED II amendment has included efforts to bit by bit diminish explicit biofuel classes and yearningly supplant them with those considered fit for meeting sustainable power source targets (Palm Oil Today, 2018).

The European Parliament's situation on RED isn't the last word. EU pioneers at that point haggled to conclude the RED draft. Arrangements between the European Commission, the European Parliament and the Council of the European Union to endorse the content of the last RED trade-off are known as 'trialogue.' Whether to boycott palm oil biofuel or not is a fundamental issue in trialogue exchanges. European Parliament concurs and the choice to help it. The new RED will, at that point, push ahead and become EU law (Palm Oil Today, 2018). On June 14, 2018, the trialogue reached a political agreement to optimize the use of renewable energy in Europe. In 2030, EU members a binding energy target of about 32\%. This percentage may add after a review in 2023 of an initial percentage of $27 \%$ (Palm Oil Today, 2018).

After a political agreement deals, the European Parliament and the European Union Council are required to approve the directive text formally. With approval from the two legislative bodies, a few months later, the renewable energy directives were renewed to RED II, which was published in official EU journals and entered into force 20 days after. EU member countries must adopt new RED II elements and make them part of national law no later than 18 months after the date of the section into power.

The consequences of the trialogue understanding and palm oil contain the aftereffects of a three-path arrangement of the European Parliament, part states, and the European Commission to manage EU sustainable power source approaches in the next 
decade. The sustainable power source order for the period 2021-2030 (RED II) presents a coupling objective for 'sustainable power source in transportation' of $14 \%$ with the most significant portion of biofuel produced using $7 \%$ food crops and extra activities planned for restricting the utilization of palm oil. Another coupling objective of $14 \%$ for a sustainable power source in transportation by 2030 will present, joined by an order forced on fuel suppliers. The portion of biofuels in transport in the EU was 4.2\% in 2015 (All Africa, 2018).

Member countries will be permitted to advance biofuels produced using food or food plants until 2030. They can compute sustainable power source focuses up to the 2020 utilization level with a limit of $7 \%$ of the last gross vitality utilization in street and rail transportation. Part nations that decide to confine their utilization of food-based biofuels to underneath $7 \%$ can diminish their traffic by $14 \%$. Individuals expressed that right now, utilizing food or plant food in travel to levels underneath $2 \%$ will be permitted to expand their utilization to a limit of $2 \%$. The endorsed RED content II specifies the commitment of biofuels, bio-liquid powers, and explicit classifications of biomass energize created from food and feed crops. (European Parliament, 2018).

Commitments of biofuels at generally safe of ILUC will be excluded from these cutoff points dependent on target measures. RED II does not provide specialized treatment for any of the vegetable oil sources, including canola, sunflower seeds, soybeans, or palm oil. In the trialogue agreement, the European Commission is tasked with making a report on the status of the expansion of the creation of food crops and feed plants around the world no later than February 1, 2019. The European Commission will impose a Delegated Act in determining the criteria for certifying food stocks whose production areas expand significantly to produce high carbon.

EU palm oil separation at that point created when the European Commission gave a draft strategy entitled Delegated Regulation Supplementing Directive of the EU Renewable Energy Directive II presented by the European Commission on March 13, 2019. The European Commission ratified the Delegated Regulation No. C (2019) 2055 Final on High and Low ILUC Risk Criteria on Biofuels. In the draft Delegated Regulation, the European Commission will use the ILUC criteria as a criterion of high vegetable oil as an unsustainable and high-risk commodity. This draft will publish in a journal in Europe, and if no member country sues, it will require ratification as a standard rule. The determination is carried out by the European Commission based on the latest scientific information as a commitment to anti-discrimination measures in preparing reports and delegated actions (EEAS, 2018).

RED Text II sets nonpartisan and target measures in determining the contribution of biofuels to renewable energy targets for EU member countries without the choice of certain types of raw materials. With RED II, EU member countries are free to import and utilize biofuels and raw materials as previously done. The European Commission ensures that each implementing regulation will be reasonable, adjusted, and dependent on solid logical proof to guarantee the accomplishment of sustainable power source in harmony with the international trade regime (EEAS, 2018).

The rules of the European Union Council Commission are unfair to other vegetable oils. The criteria to be used in the ILUC is a year based on 2008-2015 global deforestation data, which is closely related to the highest level of palm oil deforestation. Whereas in 2015, Indonesia began to take policies to make regulations on oil palm plantations, and it looks lost control. Permission to plant palm trees is carried out annually during the reign of Susilo Bambang Yudhoyono. Since President Jokowi, the problem of 
oil palm plantations began to restrain by implementing a moratorium on oil palm cultivation (Basara, 2019).

\subsection{Palm Resolution}

Resolution regarding palm oil and rainforest deforestation was passed by the European Parliament through a vote in a plenary session in Strasbourg on April 4, 2017. With the enactment of this resolution reflects the discriminatory treatment of palm oil and its producing countries (Prabowo, 2017). It means that it also contradicts the EU itself, whichEU position as a victor of open, rules-based free, and reasonable exchange. The issuance of this resolution received serious attention from the Government of Indonesia.

Around 27 million tons of palm oil are exported to several countries, while the remaining 6 million tons will consume domestically. The volume of palm oil exports has successfully contributed to state revenues in 2016, amounting to USD17, 8 billion, or $12.3 \%$ of the all-out estimation of Indonesia's fares. While in the non-oil and gas sector, this amount represents $13.6 \%$ of all Indonesian non-oil and gas exports. Indonesia's palm oil products export to various countries. The data in 2016 shows that the primary buyers of Indonesian palm oil, sorted by the number of the most significant imports, are India, the EU, China, Pakistan, the Middle East, Africa, and the United States. The Indonesian Palm Oil Association (GAPKI) estimates the total demand for vegetable oil in the world by 2025 will increase to 226.7 million tons. In 2017, palm oil held around $30.8 \%$ of the full vegetable oil used by the world (Idris, 2017).

From these various data, it can look that the palm oil industry is a strategic industry that is of significant value to Indonesia, particularly on the export side. Therefore, Indonesia has an interest in continuing to develop its palm oil industry by paying attention to the productivity, environmental sustainability, and maximum impact on the country's economy, especially small farmers, through the application of sustainability principles (BPPK, 2017). In this association, the advancement of a manageable palm oil industry is following Indonesia's promise to accomplish the objectives of the 2030 Sustainable Development Goals Agenda.

Information and data identified with the advancement of oil palm and backwoods the executives in creating nations that used to draw up a European Parliament Resolution were likewise mistaken and responsible, including in the case in Indonesia. Also, this resolution overrides the multi-stakeholder approach (Ardhian, 2017). The leading cause of deforestation is not from oil palm plantations. A European Commission study in 2013 said that out of a total of 239 million hectares of globally deforested land in the past 20 years, the livestock grazing sector accounted for the most, 58 million hectares. While 13 million hectares came from soybeans and 8 million hectares came from corn. Only around six million hectares are deforestation from the palm oil sector. From these data, the contribution of the palm oil sector to global deforestation is only $2.5 \%$ (European Commission, 2013).

Palm oil can be a piece of the answer for decrease ozone harming substance emanations and contribute decidedly to the expanding worldwide interest for biofuels rather than petroleum products. Palm oil, until this point in time, is the most profitable vegetable oil as far as land zone proportion and creation yield. Compared to the return of the sunflower, which is 0.52 tons/hectare/year and soybean $0.45 /$ ton/hectare/year, production from oil palm can reach 4.27 tons/hectare/year. Even canola production is still very far away because it only produces 0.60 tons/hectare/year (Indonesian Ministry of 
Foreign Affairs, 2017). The proposed single certification scheme in the European Parliament Resolution has the potential to increase unnecessary barriers to trade. It is counterproductive to efforts to improve the quality of palm oil sustainability.

Indonesia itself already has a mandatory, Indonesia Sustainable Palm Oil (ISPO). This policy has a focus on environmental protection and management. As such, recommendations for phasing out the advantage of palm oil as outlined in the Resolution of the European Parliament are considered protectionist behavior and are not fundamental. The goal suggests the advancement of canola oil and sunflower seeds, which are not more productive and environmentally friendly when compared to oil derived from palm oil. On the other hand, the resolution also overrides the rights of farmers who look for oil palm. Around 16 million people depend on the palm oil sector, both directly and indirectly. $41 \%$ of them are small farmers in rural areas (Indonesian Ministry of Foreign Affairs, 2017).

A diplomat with the EU Delegation to Brunei and Indonesia, on Tuesday (17/9) made plans to stop palm oil-based biofuels, including Indonesia. The EU Renewable Energy Directive, which will begin in 2024 to stop biofuels, can still be revised and amended. Under the new EU Renewable Energy Directive, palm oil subsidies can continue to be undertaken by member countries to achieve their renewable energy targets. They can be calculated until 2020 as renewable energy when the number of incentives on biodiesel for palm oil will be frozen at the level of 2019. Likewise, there will be a gradual elimination from 2024 to 2030, considering palm oil as renewable energy. The law is dynamic and will be revised, which revises all data based on the latest impacts made by Indonesia and Malaysia and other palm oil producers in the year 2021, which has also been recorded from all sustainability policies.

The data used in the 2008-2015 reference period by the European Union can be challenged. Thus the revised data has the latest data, including the expansion of palm oil occurring, were abandoned or degraded land has led to further deforestation and encroachment of peatlands. Likewise, in 2021, the European Union has a significant data revision that leads to a review of the regulation in 2023, which, if data changes are needed to revise EU criteria. This revision applies to all commodities, and will be carried out on other oil-producing crops such as soybeans, and not just focus on palm oil. So that the European Union has a big window of opportunity when there are no changes to collaborate with producers of sustainable palm oil.

\subsection{The Green Movement}

Movement is a movement that shows concern for environmental issues, sees integrity to be preserved both for their interests and the interests of individuals. Its membership is as diverse as severe scientists, political activists, rich and poor people in all countries, and people with various religious philosophies. United by the desire to protect the environment, the green movement has succeeded in raising public awareness about environmental issues, has won several significant legal victories, and has influenced government policy.

Conservation groups have long campaigned to preserve the natural environment and wild species. In Europe alone, organizations such as Friends of Nature and National Trust were formed in the nineteenth century. Concerns about nuclear power, toxic waste, acid rain, and road-building find expression in increasing political activism and in changing personal choice patterns about how to live, what is bought or not bought, and 
more (encyclopedia.com.).Europe is one continent that cares about the climate, which creates many opportunities and challenges. Changes in the environmental environment are a threat to excitement to Europe and the world. : (A). absence of greenhouse gas emissions in 2030 (b). economic growth is separated from the use of resources. The increase in global temperature must be $1.5^{\circ} \mathrm{C}$.

Green policies are efforts/actions and instruments carried out by the government or other parties, which have goals and potential to reduce $\mathrm{CO} 2$ emissions. Reducing $\mathrm{CO} 2$ emissions is not only limited to specific fields such as the energy sector, for example. A broad-based approach is needed to encourage adjustment of cross-economic behavior because energy consumption based on fossil resources can be reduced in many parts of the economy. The main objective of this instrument policy is to minimize environmental damage with minimum economic costs. Policies can drive structural changes towards a low carbon economy.

\subsection{Green Leaders in the European Union (EU)}

The green revolution was initiated by Ford and the Rockefeller Foundation, which developed wheat in Mexico (1950) and rice in the Philippines (1960). Green revolution wins rice, corn, wheat, and more. (cereals are grains). Through the application of this nontraditional technology, there has been an increase in food yields, which has doubled and made it possible to plant triples for rice in certain places.

Regarding climate, the climate is one of the biggest problems in the world. Why is that? According to WHO, the issue of diseases that occur in Europe is caused by the environment. As soon as possible, smoke in Indonesia that has an impact on Malaysia in several studios that explain the role of the region/environment that is very important in each region so that it can get prosperity. A recent phenomenon in the European Union where Europe was decided that he is a green leader. After negotiating the European Union to become a leader in actualized deforestation management through EU communications on Enhancing EU Action for the improvement and restoration of the world's forests on July 23, 2019, EU leaders will ask for a commitment to increase greenhouse gas emissions to zero by 2030 .

Current climate change has become a familiar term among the community. As we know that the changes that we have felt such as high rainfall, windshield angina, dry season, etc. Based on thousands of studies, ensure that increased concentrations of home gases cause global warming. Greenhouse gas (GMK) is a type of gas that can trap solar radiation. In the carbon market, what is traded is the right to the emission of greenhouse gases in units of tons- $\mathrm{CO} 2$ equivalent (tons of $\mathrm{CO} 2$ equivalent). The reason here can be the right to release greenhouse gases or the right to reduce greenhouse gas emissions.

To meet this target, the European Union will encourage more green investment and adjust all its budgets. European Union communications began to target the tropics, including palm oil, which Europe sees as a source of deforestation. Ursula von der Leyen as the leader of the European Union, the new Chair of the European Union Commission set ambitious targets, making the European Union a "carbon neutral" region until 2030. A more controlled European Green Treaty in businesses supported, enlarged, and supported for forests, national parks, and green spaces in Europe.

The European Union issued three policy resolutions, the Renewable Energy Directive and Delegated Regulations that discriminate against palm oil. What is worrying going forward, there may be other EU problems that are tighter on palm oil, more quickly 
adding to the food/health industry. In 2014, EU countries agreed to work agreements on climate and energy, including EU policy targets and targets for the period 2020-2030. The goals for 2030 include (1) seeking $40 \%$ of gas emissions, (2) a maximum of $27 \%$ renewable energy consumption, and (3) a maximum energy savings of $27 \%$ compared to projected energy consumption. EU climate and energy targets are bound to support EU support. Related to sustainability in the UN, climate diplomacy is the second realm of EU leadership in the field of climate policy (Groen et al 2012).

Environmental problems are problems that cannot be taken in the 20th century. Public attention to various groups in the world as a whole is related to environmental issues. The environmental problem is one that is not important in the European Union policy. The European Union is developing various laws, action programs, and directives to improve the quality of the environment, including multiple issues related to saving the EU community, such as climate change, ozone depletion.

In dealing with global environmental problems, the European Union asks to participate in solving complex issues, including the issue of climate change. The European Union also shows a desire to develop international environmental governance and form the world Environmental Organization. The Green Party in Europe can be accepted as one of the points which then directs governments in Europe to discuss environmental issues more seriously. The seriousness of this government is based on the fact that Europe does not have natural resources that can be produced.

Finding policies for environmental protection is considered necessary as anticipation of environmental damage that can recognize the difficulty of finding natural resources. In addition to increasing and enhancing natural resources, the aim of creating environmental policies by European governments is to support environmental preservation, improve environmental quality, and protect human health.

Sustainable development can be carried out as economic development in the European region carried out with natural resources so that the environment for European people is in a decent and good condition. Industrialized and developed countries have high awareness in meeting the standards of sustainable development in the European region. Europe began to show concern for the environment after the holding of the Environmental Conference in Stockholm by the United Nations (UN) in 1972. This conference succeeded in making countries in Europe, and others moved to help actively voice environmental problems and look for various activities to support sustainable development. Evidence of European participation in expressing environmental issues is the establishment of an Environmental Action Program (EAP) to address environmental challenges that exist in Europe.

The European unit has three main focuses in responding to environmental problems.

- The green economy of the European Union

A 'green' economy is an economy in which people's policies and innovations create more value every year while maintaining the natural systems that sustain us. Green development is management carried out by the European Union in environmental protection, but competitive in the global market. Management is carried out by the European Union.

The green economy is done by using environment-based technology that can be implemented clearly and can spread to various countries in Europe. With the concept of a low-carbon economy, all activities aimed at increasing the use of low-carbon dioxide green energy sources, increasing the pressure of greenhouse gases into the earth's atmosphere, can be improved. The reason is that the increase in the concentration of gas 
in the atmosphere increases, so the solar heat trapped in the atmosphere becomes more extensive and more complicated.

- Protect Nature

Efforts in achieving development that is considered important, because it is a human life support system, is needed to treat it. The European Union has a concern for natural resources and rare species of shelter. One of the policies is Natura 2000 is a network of 26,000 natural areas of protection, protection of nearly $20 \%$ of the EU border region as a place of human activities managed

- Maintain the health and well-being of people living in the European Union

In realizing sustainable development in the European area related to the feasibility of the European region as a place of human habitation. The categories that must be considered, such as water, air pollution, and chemicals are the main focus of people's attention to the environment. European Union policy in realizing adequate health and housing in three ways, namely meeting the needs for drinking water and bathing, develop air quality and reduce planning, and reduce the potential for hazardous chemicals.

The European Union has also optimized energy use in industrialized countries so that it does not have an impact on the environment. The EU's commitment and attention to this have resulted in a series of policies, including eco-labeling, the Energy and Climate Change Package, and the Fuel Quality Directive (Schaus and Lendle 2010). Several European environmental NGOs have asked the European Commission to issue a strong agreement, which approves important products - products related to deforestation to the European market (Andi Sparringa: 2019).

Officially, the European Union NGO has given an open letter related to palm oil saying "To the President of the Republic of Indonesia, the President of the European Union Council and the Leaders of European Union Member States: Addressing the Impact of Business Oil Palm Plantations, namely: Destroying Forests, Land grabbing, Human Rights Violations, Corruption, and Environmental Disasters: We have examined the Palm Oil and Deforestation documents from the Rain Forest (Palm Oil and Tropical Forest Deforestation), which mention industrial developments that are the goals of forest development and climate change. Besides, in the context of the Directive Revised Renewable Energy (RED II), the European Parliament (EU) is asking for permission related to biodiesel cultivation in 2020. In dealing with Europe, the cooperation modality between Indonesia and the European Union is quite significant by agreeing to the approval of Forestry Law Enforcement Governance and Trade (FLEGT).

\subsection{The EU-Indonesia Trade War (Case Study)}

The Government of Indonesia, through the Independent Mission of the Republic of Indonesia (PTRI) in Geneva, Switzerland, formally filed a lawsuit against the European Union at the WTO on December 9, 2019. File suit against Directive Energy Directive II (RED) II) and EU Delegation Regulatory policy. This policy is a consideration for discriminating against Indonesian palm oil products. This discrimination is detrimental to the export of Indonesian palm oil products on the EU market. Through the RED II policy, the EU requires that from 2020 to 2030, the use of fuel in the EU comes from renewable energy. Furthermore, the Delegated Regulation, which is the implementing regulation for RED II, categorizes oil palm into a commodity that has a high-risk Indirect Land Use Change (ILUC). 
As a result, biofuels made from crude palm oil are not included in the EU renewable energy target, including Indonesian palm oil. Therefore the Indonesian government objected to the elimination of the use of biofuel from palm oil by the EU. Besides, it will damage Indonesia's palm oil exports to the EU; it will also give a bad image for palm oil products in global trade and threaten Indonesia's export markets. Statistics from BPS show that the export value of palm oil and biofuel / Fatty Acid Methyl Ester (FAME) to the European Union shows a negative trend in the last five years. The export value of FAME reached 882 million US dollars in the January-September 2019 period, down 5.58 percent compared to the same period in 2018 of 934 million US dollars. While the value of exports of palm oil and FAME to the world also recorded a decrease of 6.96 percent from 3.27 billion US dollars in the January-September 2018 period to 3.04 billion US dollars per year (year to year).

EU environmental diplomacy is moving towards a new era after Indonesia's response to the threat of trade war between the European Union and Indonesia. Indonesia threatened to take action to boycott EU imports in Indonesia and submit a case to the World Trade Organization Dispute Resolution Agency. Indonesia's environmental diplomacy is now strong against the EU RED II, which states that the EU RED II is too discriminating against Indonesia and neighboring Malaysia. From information obtained from an interview with Sugardiman in 2019, EU RED II has the aim to protect inefficient European rapeseed and sunflower. Indonesian palm oil as a real threat to European sunflower farmers. Ambassador Guérend argued that there was an agitation against EU environmental diplomacy that triggered nationalist sentiment in Indonesia, which led to arguments for EU external intervention on sovereign states.

There are several important points related to the potential of the EU-Indonesia trade war. First, the EU does not want to be involved in a trade war. The EU Ambassador stated that if this were possible, let the EU and Indonesia have a mutually beneficial solution to sustainability rather than ignite and boycott each other. It could harm both parties. The European Union does not want an emotional boycott from the Indonesian government, which will hurt trade cooperation between the European Union and Indonesia. The EU Ambassador wants to emphasize the health benefits for Indonesia and the EU in their bilateral trade. The focus of EU environmental diplomacy is the issue of sustainability. EU RED II is a way for Indonesia and the EU to have a positive amount of play on sustainability issues. The potential trade war between Indonesia and the EU emphasizes the question of justice and fairness in international trade. However, the Indonesian government does not highlight the benefits of the EU RED II in bringing improvements in Indonesia's palm oil governance.

This paper adds that the implementation of the "soft power" approach is needed to ensure practical impacts on sustainable palm oil. This paper proposes that the improvement of the ISPO will become carrots for palm oil companies, and the EU RED II will be the Rattan for sustainable palm oil offenders.

According to the author, this is the meaning behind the ambassador's statement of mutual benefit; then, the EU and Indonesia have a consensus to resolve the palm oil dispute in the WTO World Trade Organization. The EU ambassador said: "If there is a conflict of interest in trade, it is better to have evaluative requirements at the WTO. That is the right way. We believe that in many parts of the world, disputes must be resolved at the WTO. In this journal, the EU highlights the importance of cooperation bodies between the WTO governments in deciding solutions for EU and Indonesia trade disputes. Therefore, the WTO is the authority to review the implementation of the country's most 
preferred principles that trade policies towards certain countries will apply to all countries.

\subsection{Deforestation of Indonesia's forests is the focus of the EU}

The European Union plans to ban the use of menta palm oil as a raw material for biofuel. Palm oil is considered a commodity that has a high risk of the environment. Based on the new design issued by the EU, oil palm oil is classified as an unsustainable product. This regulation will be tested for two months per 2019 if in this period there are no objections from European Union countries, this regulation will be published in the official journal of the European Union, meaning that it will become applicable law in the European Union. The European Commission concluded that the mainstay of Indonesia's sister culture community, namely palm oil, causes excessive deforestation, and its use as vehicle fuel, aka biodiesel, must be removed.

But based on data from the Directorate General of Forestry and Environmental Planning (PKTL) of the Ministry of Environment and Forestry, the results of Indonesia's forest monitoring in 2019, showed that the area of forested land throughout the Indonesian mainland was 94.1 million ha or $50.1 \%$ of the total land area. Of this amount, $92.3 \%$ of the total forested area, or 86.9 million ha, is in the forest area.

In 2019, the area of oil palm plantations in Indonesia was estimated to have reached 14.68 million hectares, or increased nearly 50 times. Even when referring to the reconciliation data of the calculation of the area of national oil palm cover in 2019 , the figure is even greater at 16.38 million hectares.

The increase can be seen from the total production of palm oil (palm oil and palm kernel) 2018 was 48.68 million tons, consisting of 40.57 million tons of crude palm oil (CPO) and 8.11 million tons of core oil palm kernel oil (PKO). The total production came from smallholder oil palm plantations of 16.8 million tons $(35 \%)$, large state estates of 2.49 million tons $(5 \%)$, and large private estates of 29.39 million tons $(60 \%)$. The representation of the use of vacant land and deforestation as oil palm plantations is very high, and this has become the main focus of the European Union, causing trade problems between Indonesia and Europe to be slightly disrupted.

Data from the Directorate General of PKTL also shows Indonesia's deforestation trends are relatively lower and tend to be stable. Net deforestation in $2018-2019$, both inside and outside Indonesia's forest area is 462.4 thousand ha. This figure is derived from the gross deforestation rate of 465.5 thousand ha, minus the reforestation rate (the result of satellite imagery monitoring) of 3.1 thousand ha. The highest area of deforestation occurred in the secondary forest class, namely 162.8 thousand ha, where $55.7 \%$ or 90.6 thousand ha were inside the forest area, and the remaining 72.2 thousand ha or $44.3 \%$ were outside the area Forest.

As a comparison, the results of Indonesia's forest monitoring in 2018 show that the net deforestation in 2017-2018 both inside and outside Indonesia's forest area is 439.4 thousand ha, which is derived from the gross deforestation rate of 493.3 thousand hectares minus reforestation (satellite imagery monitoring results) of 53.9 thousand ha. So the author concludes in this section, the form of EU protest against Indonesia that deforestation for oil palm plantations is unsustainable energy.

\section{Conclusions and Recommendations}


The European Union wants to change all types of transportation. At present, the European Union is designing for its National Energy and Climate (NECP), which will prepare the right mix of renewable energy to start the future. This plan is until the end of the year. However, in Farm Europe, in its institution, now the injure is issuing a simple design, actually less useful because it improves the calculation method. However, the price to change to an electric car, which any country does not count according to this study, and the slow progress in electrification infrastructure can be a new challenge. European Union, The direction of renewable energy, is that the European Union must have made renewable energy, which has long been criticized and made a good impact on the European Commission.

As part of the 'Clean Energy for All Europeans' package, EU member states are revising the Renewable Energy Directive to encourage renewable energy use and help block meeting their needs under the Paris Agreement. The EU must make renewable energy, while the European Parliament still wants to seek agreements in various types. The EU market is always open to increasing bilateral trade even in the region; the EU is still open to start negotiations and make global-regional agreements. But as we have explained first, the EU has taken many important things like the Renewable Energy Directive that has been reducing carbon emissions globally as a form of EU commitment to the Protocol. 


\section{BIBLIOGRAPHY}

\section{Journal}

Robertua, Verdinand. (2019) 'Environmental Diplomacy: Case Study of The EUIndonesia Palm Oil Dispute.' MANDALA, JurnalHubunganInternasional Vol.2 No.1

Bayne, N \&Woolcock, S. (2007). The New Economic Diplomacy: Decision-Making and Negotiation in International Economic Relations. Aldershot: Ashgate.

EU Green Paper Tahun 2006.

Directive 2009/28/EC of The European Parliament and of The Council.

Belkin, Paul, September 11 2007. The European Union's Energy Security Challenges, CRS Report of Congress.

European Commission. 2007. Energy Corridors: European Union and Neighboring Countries, European Communities Publication, Belgia.

Nies, Susanne. 2008. Oil and Gas Delivery to Europe: An Overview of Existing and Planned Infrastructure, The French Institute for International Relations (Ifri), Paris.

Council of European Union, Council Conclusion on "Second Strategic Energy Review An EU Energy and Solidarity Action Plan, Brussels, February 2009.

European Community. 1997. Consolidated Version of the Treaty Establishing the European Community. Official Journal of the European Communities 325: 173306.

http://eurlex.europa.eu/legalcontent/EN/TXT/HTML/?uri=CELEX:12002E/TXT\&from=E $\mathrm{N}$

European Parliament \& Council of the European Union. 2009. Directive 2009/28/EC of the European Parliament and of the Council of April 232009 on the Promotion of the Use of Energy from Renewable Sources and Amending and Subsequently Repealing Directives 2001/77/EC and 2003/30/EC. Official Journal of the European Union L140(June): 16-62.

\section{Website}

Direktorat Jenderal Perkebunan. 2014. Statistik Perkebunan Indonesia Komoditas Kelapa Sawit 2013-2015. Direktorat Jenderal Perkebunan, Jakarta.

Basara, D. (2019, April 9). Jokowi, Mahathir Tell Brussels to Get Ready for Retaliation Over Discriminatory Palm Oil Restriction. Diambilkembalidari Jakarta Globe: https://jakartaglobe.id/ context/jokowi-Mahathir-tell-Brussels-to-get-ready-for retaliation-over-discriminatory-palm-oil restriction/

European Commision. (2013). The Impact of EU Consumption on Deforestation: Comprehensive Analysis of the Impact of EU Consumption on Deforestation. Diambilkembalidari HTTP:// ec.europa.eu/environment/forests/pdf/ 1.\%20Report\%20analysis\% 20of\%20impact.pdf 
European Union. (2018, Juni 25). Palm Oil: Outcome of the Trilogue of the EU's Renewable Energy Directive (RED II). Dipetikapril 10, 2020, from https://eeas.europa.eu/delegations/ indonesia/46646/palm-oil-outcome-trilogueeu\%E2\%80\%99srenewable-energy-directive-red-ii_en

Lee, J. S. (t.thn.). 2014) Environmental impacts of large-scale oil palm enterprises exceed that of smallholdings in Indonesia. Conservation Letters.7(1).

Palm Oil Today. (2018, Maret 12).Trilogue Negotiation to Determine Palm Biofuels Ban.Dipetikapril 10, 2020, from HTTP:// palmoiltoday.net/trilogue-negotiationswill-the-palm-biofuelsban-prevail/

All of Africa. (2017). New EU Biofuel Rules Not Enough to Help People or the Planet. Dipstick April 10, 2020, from https:// allafrica.com/stories/201806140456.html

Sari,E.V.(2017,April17).MenteriPerdaganganBerencanaBikinStandarSertifikatMinyakS awit.Dipetik April 10, 2020, dari https://www.cnnindonesia.com/ ekonomi/ 2017041716375992-208126/mendag-berencana-bikin-standar-sertifikatminyaksawit

Policy Analysis and Development Agency. (2018). Palm Oil Diplomacy, Center for American and European Region.Diambilkembalidari Minister of Foreign Affairs of the Republic of Indonesia.

World Resources Institute. (2017, Oktober 23). Technical Blog: Caveats to the 2016 Tree Cover Loss Data, Explained. Dipetikapril 10, 2020, from https://www.wri.org/blog/2017/10/ technical-blog-caveats-2016-tree-cover-lossdata-explained

Indonesia-Investments.(2017) Minyak Kelapa Sawit https://www.indonesiainvestments.com/id/bisnis/komoditas/minyak-sawit/item166

BBC (2019) Kelapasawit, ancaman perang dagang RI-UniEropadanenamhallainnya https://www.bbc.com/indonesia/indonesia-47663602

Prabowo, E. (2017, Desember 5). Resolusi Sawit Parlemen Eropa yang Merugikan Indonesia.

https://ekonomi.kompas.com/read/2017/12/05/155319126/resolusisawit-

parlemen-eropa-yang-merugikan-indonesia

Badan Pengkajian dan Pengembangan Kebijakan-BPPK. (2017). Diplomasi Sawit. Diambil kembali dari Kementerian Luar Negeri.

Idris, M. (2017, April 18). Ekspor Sawit ke Eropa Dihambat, Apa Dampaknya Bagi RI? https://finance.detik.com/berita-ekonomi-bisnis/d-3477946/eksporsawit-keeropadihambat-apa-dampaknya-bagi-ri

Ardhian, M. (2017, April 10). Mendag Curigai Kepentingan Bisnis di Balik Resolusi Sawit Eropa. https:// katadata.co.id/berita/2017/04/10/mendag-curigaikepentinganbisnis-di-balik-resolusi-sawit-eropa

European Commision. (2013). The Impact of EU Consumption on Deforestation: Comprehensive Analysis of the Impact of EU Consumption on Deforestation. http:// ec.europa. eu/environment/forests/pdf/ 1.\%20Report\%20analysis\% 20of\%20impact.pdf

Kementerian Luar Negeri RI. (2017). Tanggapan atas Resolusi Parlemen Eropa Tentang Minyak Sawit. Diambil kembali dari https://www.kemlu.go.id/id/berita/Pages/Tanggapan-AtasResolusi-ParlemenEropa-Tentang-Minyak-Sawit-.aspx

https://money.kompas.com/read/2019/12/17/121400126/perang-dagang-indonesia-unieropa-sawit-ditolak-nikel-bertindak di akses padatanggal 10/04/2020. 
https://ec.europa.eu/jrc/en/jec/renewable-energy-recast-2030-red-ii (12/07/2020)

https://thepalmscribe.id/opportunity-for-sustainable-palm-oil-before-red-ii-starts-in2024-eu-diplomat/ (11/07/2020)

Robert Falkner (2006) “The European Union as a 'Green Normative Power'? EU Leadership in International Biotechnology Regulation Center for European Studies, Harvard University Department of International Relations, London School of Economics: page (7).I

AndiSparringa "Indonesia dan Gelombang Hijau Uni Eropa", Juru Bicara KBRI Brussel untuk isu sawit/ Fungsi Ekonomi KBRI Brussel, Belgia.

(Green Policies in the EU: A review and (Ec-IILS JOIN DISCUSSION PAPER SERIES NO.14 n.d.) n.d., 2-3)

eprints.undip.ac.id/41570/7/Jurnal_karya_ilmiah.pdf

https://katadata.co.id/berita/2019/10/07/kelapa-sawit-sebagai-penopang-perekonomiannasional

http://ppid.menlhk.go.id/siaran_pers/browse/2435 